\title{
California Crop Improvement Association Disease Inspection Program: Production Practices for Clean Seed
}

F.J. Sundstrom, P. Guzman, and R.F. Stewart

Summary. Pathogen free seed has long played a critical role in reducing or eliminating the severity of various diseases in commercial fields. The California Crop Improvement Association (CCIA) provides quality assurance services to the seed industry that are designed to promote the production, distribution and use of high quality seedstocks for agricultural production. To that end, CCIA has developed a Disease Inspection Program to assist vegetable seed producers in eliminating the bacterium, Acidovorax avenae subsp. citrulli (AAC), from cucurbit (Cucurbitaceae) seedstocks. This program utilizes recommendations and standards beginning at parent seed production of hybrids through the production of commercial seedlots. Training of field personnel, field inspections and tissue tests, followed by growouts of at least 30,000 seedlings are used as components of this quality assurance program.

The bacterium, AAC, is a well-known seedborne pathogen in watermelon (Citrullus lanatus) and other cucurbits. Infection

L by AAC results in a disease called bacterial fruit blotch (BFB).

Since the late 1980s, reports have indicated that the presence of BFB in transplants and in commercial watermelon fields has resulted in devastating crop losses and significant litigation. The production and use of clean seed plays a critically important role as a control measure of this disease. The CCIA Disease Inspection (DI) Program is a voluntary quality assurance program that has been developed between CCIA and the vegetable seed industry to assist in the production of pathogen-free seed.

\section{Seed testing}

Seedborne pathogen transmission of BFB is one of the primary means of crop infection (Latin and Hopkins, 1995; Latin, 1996). Early reports of economic damage indicate that as few as one infected seed in 9,000 can result in an outbreak of BFB in greenhouse transplants (Rane and Latin, 1992). As a result, CCIA recommends that seed screening and testing begin in parent seed programs. Although other testing methods have been employed by various seed laboratories, the seedling growout method currently remains the most effective and is the standard assay for BFB detection (Walcott et al., 2001).

California Crop Improvement Association, Seed Certification Center, University of California, Davis, CA 95616 
Participating companies are obligated to perform the seedling growout test according to established procedures of the American Seed Trade Association Ad Hoc Watermelon Fruit Blotch Committee (Egel et al., 1994). The value of parent or foundation seed is very high and seed volumes are characteristically low. Consequently, if the seedlot is less than 300,000 seeds, $10 \%$ by count of the seeds should be tested. If the lot is greater than 300,000 seeds, a 30,000 seedling growout must be conducted.

CCIA permits those companies participating in the DI Program to conduct seed and seedling assays using their own pathology facilities and staff. A facility visit is conducted at each site where testing will occur to assure that adequate staff training and testing facilities exist. In addition, CCIA has approved a number of seed pathology labs to perform tests for this program. Copies of all test results must be forwarded to CCIA before tagging of seed.

\section{Field and transplant inspections}

Each company participating in the DI Program must complete an application form and forward it to CCIA no later than the date of seeding in the greenhouse or field. A minimum of two greenhouse or field inspections will be performed during the growing season. Additional inspections may be performed as deemed necessary to verify possible pathogens. These inspections may be done by CCIA personnel and/or a qualified seed company inspector. As needed, CCIA conducts BFB training workshops of seed company personnel. Those personnel that have successfully completed one of these workshops are considered qualified inspectors. Qualified inspectors are familiar with, and agree to follow CCIA DI Program policies and procedures. Frequently, qualified seed company inspectors conduct the first inspections of transplants and directseeded fields, yet all fields must be inspected by a CCIA inspector or their designated agent at least once before harvest.

Commercial seed fields are inspected at the transplant or first true leaf stage and at the mature melon stage. Plant and fruit symptoms are well documented (Isakeit,1999; Maynard and Hopkins, 1999). In the greenhouse, each flat of transplants will be inspected for cotyledonary symptoms. One infected seedling disqualifies all plants in that range of the greenhouse complex. In a directseeded field, the first inspection of seedlings should be made before cotyledon shed. The second field inspection is made at the mature melon stage by examining as many fruit as possible during field walks. Ideally, watermelons are inspected before wind-rowing because symptoms are most apparent on upper fruit surfaces. Fruit are easier to examine if inspection is conducted after vine breakdown.

Inspections are conducted by walking one of every two rows in fields smaller than 1 acre (0.4 ha). For fields between 1 and 5 acres (2.0 ha), one of every four rows are walked, and for fields greater than 5 acres, one of every eight rows must be walked. These numbers exceed phytosanitary requirements (California Dept. of Food and Agriculture, 1985).

If suspicious tissues (water-soaked lesions with irregular margins, some of which on fruit may brown and crack with subsequent exudate) are observed, tissues must be sampled and tested immediately using the AgriCheck system for AAC (Hydros Environmental Diagnostics, Inc., Falmouth, Mass.). All fields are randomly sampled (a minimum of two to three times in various locations and bulked) in order that each field has been tested whether or not classical AAC symptoms are found. The AgriCheck system is a double antibody sandwich (DAS) enzymelinked immunosorbant assay (ELISA) test that is designed to detect AAC within 15 to $20 \mathrm{~min}$ in the field. The sensitivity of this ELISA is sufficient that up to nine individual tissue samples may be bulked for each test. If results are positive, confirmation of the pathogen is necessary by lab isolation and identification, or by seedling growout. Results of all tests must be submitted to CCIA. One infected seedling disqualifies the entire seedlot. A seedlot constitutes the production of seed from a contiguous field.

CCIA will issue a report on each seedlot upon receipt of all company inspection and test reports. Lots that are eligible can be tagged with a CCIA seal indicating that the lot tested negative for the presence of BFB. Seed companies are expected to maintain accurate records of each lot tagged and to maintain a 30,000 pure live seed, or
$10 \%$ by seed count archive sample for BFB testing for the duration of the marketing of that seedlot. Company records are periodically audited and failure to properly implement program procedures may result in company disqualification.

All technical, genetic and production information is handled by CCIA in a strictly confidential manner. CCIA provides all pertinent program records in support of customers in potential legal challenges.

The CCIA DI Program has been used by numerous producers of cucurbit seeds as a third-party quality assurance service for the production of pathogen-free seedstocks. As in the past, CCIA will continue to strengthen this program as more is learned about the epidemiology of the ACC bacterium. Currently there is consideration of expanding the program to include additional host-pathogen combinations of economic importance to the seed industry.

\section{Literature cited}

California Department of Food and Agriculture. 1985. Phytosanitary certification. Certification of fruits, vegetables and plants. Q.C. Circ. 204. CDFA, Sacramento, Calif.

Egel, D.S., R.D. Gitaitis, D.A. Maddox, W. Weibe, and R.E. Stall. 1994. Recommendations for the detection of the watermelon fruit blotch pathogen on watermelon seeds. Amer. Seed Trade Assn. Memo, Sept. 1994.

Isakeit, T. 1999. Bacterial fruit blotch of watermelon. Texas Agr. Ext. Ser. L-5222.

Latin, R.X. 1996. Bacterial fruit blotch, p. 34-35. In: T.A. Zitter, D.L. Hopkins, and C.E. Thomas (eds.). Compendium of cucurbit diseases. APS Press, St. Paul, Minn.

Latin, R.X. and D.L. Hopkins. 1995. Bacterial fruit blotch of watermelon. The hypothetical exam question becomes a reality. Plant Dis. 79:761-765.

Maynard, D.N. and D.L. Hopkins. 1999. Watermelon fruit disorders. HortTechnology 9:(2)155-161.

Rane, K.K. and R.X. Latin. 1992. Bacterial fruit blotch of watermelon: association of the pathogen with the seed. Plant Dis. 76:509-512.

Walcott, R., D. Langston, R. Gitaitis, D. Gay, D. Hopkins, D., T. Kucharek, R. Latin, D. Egel, W. Cook, A Keinath, and B. Lovic. 2001. Guidelines for control of bacterial fruit blotch of watermelon. Natl. Watermelon Assn., Inc., Morven, Ga. 